\title{
TANGGUNG JAWAB NEGARA TERHADAP PENCEMARAN LAUT DARI LIMBAH BUANGAN PLTU DI KAWASAN PESISIR PANTAI
}

\author{
Muhammad Mutawalli \\ Universitas Islam Negeri Alauddin Makassar \\ Email : mutawallimuhammad22@gmail.com
}

\begin{abstract}
This study aims to determine how the environmental legal arrangements regarding state responsibility for marine pollution from wastewater discharged PLTU (power plant steam) in the coastal area and how the forms of state responsibility for marine pollution from liquid waste discharged PLTU in coastal areas. This type of research is normative legal research using legal material collection techniques through library research methods that are analyzed descriptively qualitatively. The results of this study are by implementing programs made by the government such as in the case of the IPLC program, PROPER, and the government to supervise, monitor, and carry out unannounced visits to companies. As IPLC is a liquid waste disposal permit aimed at business or industrial activities that use water sources as a place to dispose of liquid waste from the results of its business activities. Not only that to prevent and deal with industrial waste, the government must play an active role both through legislation. The government must intensify sustainable development, that is sustainable development with the meaning of development that is forward-looking with a view to being able to be used by present and future generations.
\end{abstract}

Keywords: State, PLTU Liquid Waste, Coastal Area

\begin{abstract}
Abstrak
Penelitian ini bertujuan untuk mengetahui bagaimana pengaturan hukum lingkungan tentang tanggung jawab negara atas pencemaran laut dari limbah cair buangan PLTU dikawasan pesisir pantai dan bagaimana bentuk-bentuk tanggung jawab negara atas pencemaran laut dari limbah cair buangan PLTU dikawasan pesisir pantai. Jenis penelitian ini adalah penelitian hukum normatif dengan menggunakan teknik pengumpulan bahan hukum melalui metode penelitian pustaka yang dianalisis secara deskriptif kualitatif. Hasil dari penelitian ini yaitu dengan menerapkan program yang dibuat oleh pemerintah seperti dalam hal program IPLC, PROPER, dan melakukan pengawasan, monitoring, maupun melakukan inspeksi mendadak ke perusahaan. IPLC adalah sebuah izin pembuangan limbah cair yang ditujukan pada kegiatan usaha atau industri yang menggunakan sumber-sumber air sebagai tempat pembuangan limbah cair dari hasil kegiatan usahanya. pemerintah harus berperan aktif baik melalui perundang-undangan. Pemerintah harus menggiatkan pembangunan berkonsep sustainable development yaitu pembangunan yang berwawasan ke depan dengan maksud agar mampu dimanfaatkan oleh generasi yang akan datang.
\end{abstract}

Kata Kunci : Negara, Limbah Cair PLTU, Kawasan Pesisir Pantai 


\section{PENDAHULUAN}

Indonesia merupakan negara kepulauan terbesar didunia yang juga merupakan negara dengan biota laut dan keluasan bahari yang diakui secara internasional. Hal tersebut selaras dengan Indonesia adalah negara kepulauan yang terdiri dari pulau-pulau. Jumlah pulau-pulau yang dimiliki Indonesia yaitu sebanyak 17.504 pulau (Badan Pusat Statistik, 2016). Secara geopolitik Indonesia memiliki peran yang sangat strategis karena berada di antara benua Asia dan Australia, serta diantara Samudera Pasifik dan Samudera Hindia (Yoshua, 2017: 97). Merujuk pada data yang ada, sumber daya pesisir merupakan sumber dan pusat biodeversitylaut tropis terkaya di dunia, dimana 30\% hutan bakau dunia ada di Indonesia; 30\% terumbu karang dunia ada di Indonesia, 60\% konsumsi protein hewani yang berasal dari sumber daya perikanan, sedangkan 90\% ikan berasal dari perairan pesisir dalam yang berjarak 12 mil laut dari garis pantai (Yono, 2017: 23).

Indonesia setiap tahunnya mengalami permasalahan lingkungan hidup yang dampaknya seakan kasat mata, untuk itu Indonesia menanggapi permasalahan lingkungan ini dengan mulai mengadopsi konsep pertanggungjawaban negara (state responsibility). Dengan mengadopsi konsep tersebut dapat menunjukkan menjadi bentuk pertanggungjawaban negara terhadap pencemaran yang mengakibatkan injury bagi negara sendiri.

Lingkungan merupakan seluruh faktor luar yang memengaruhi suatu organisme; faktor-faktor ini dapat berupa organisme hidup (bioticfactor) atau variabel-variabel yang tidak hidup (abioticfactor), dimana dapat dikelompokkan menjadi dua komponen utama lingkungan, yaitu: a) Biotik: Makhluk (organisme) hidup; dan b) Abiotik: Energi, bahan kimia, dan lain-lain (Soegianto, 2010: 1).

Pelestarian fungsi lingkungan hidup adalah rangkaian upaya untuk memelihara kelangsungan daya dukung dan daya tampung lingkungan hidup. Kekayaan keanekaragaman hayati dan sumber daya alam Negara Indonesia yang melimpah, wajib dilindungi oleh negara dan hukum. Permasalahan-permasalahan lingkungan hidup yang muncul merupakan bencana yang dapat mempengaruhi kualitas kehidupan umat manusia. Persoalan polusi (udara, tanah, air), global warming, kabut, hujan asam, erosi, banjir, dan lain-lainnya sudah terlihat sejak pertengahan abad ke-20. Persoalan mengenai kerusakan lingkungan hidup seharusnya mendapat perhatiaan dari semua pihak yang terkait dalam rangka memberikan suatu cara pandang yang baru agar dapat mengedepankan suatu upaya perlindungan terhadap lingkungan. Secara tidak langsung dapat memberikan suatu konstribusi dalam menghindari bahaya lain yang lebih parah terhadap perkembangan kehidupan manusia dan makhluk hidup 
terhadap kelestarian lingkungan hidup (Affila, Afnila, Rafiqoh.L, 2019: 138).

Dalam mewujudkan hak keadilan atas sumber daya alam dan lingkungan hidup ini, maka perlu dilaksanakan secara terpadu dan terintegrasi antara lingkungan laut, darat, dan udara. Hal ini sejalan dengan amanat Pasal 2 huruf d Undang-Undang Nomor 32 Tahun 2009 tentang Perlindungan dan Pengelolaan Lingkungan Hidup, yang mengatakan bahwa perlindungan dan pengelolaan lingkungan hidup harus dilaksanakan berdasarkan asas tanggung jawab negara; kelestarian dan keberlanjutan; keserasian dan keseimbangan; keterpaduan; manfaat; kehati-hatian; keadilan; ekoregion; keanekaragaman hayati; pencemar membayar; partisipatif; kearifan lokal; tata kelola pemerintahan yang baik; dan otonomi daerah. Selain itu juga harus diselenggarakan berdasarkan prinsip pembangunan berkelanjutan dan berwawasan lingkungan sebagaimana dimuat dalam bagian menimbang dari Undang-Undang Nomor 32 Tahun 2009 (Purnama.W, 2018: 124).

Perlindungan lingkungan dipandang sebagai sebuah kepentingan Bersama yang dapat diwujudkan jika terdapat pelanggaran dalam pencemaran lingkungan dalam lingkup regional. Perlindungan dan pengelolaan lingkungan hidup dilaksanakan berdasarkan asas tanggung jawab negara, kelestarian dan keberlanjutan, keserasian dan keseimbangan, keterpaduan, manfaat, kehati-hatian, keadilan, ekoregion, keanekaragaman hayati, pencemar membayar, partisipatif, kearipan lokal, tata kelola pemerintahan yang baik, dan otonomi daerah. Pentingnya peran negara dalam hal ini pemerintah pusat dalam perlindungan lingkungan harus terpenuhi demi menjaga kelayakan mutu hidup masyarakat dalam melangsungkan kehidupannya. Pencemaran laut merupakan sebuah peristiwa yang seharusnya menjadi tanggung jawab sebuah negara terhadap rakyatnya. Bukan sebuah opini lagi jika dampak dari pencemaran laut dalam suatu negara tentulah menimbulkan hal merugikan, terutama limbah hasil pengolahan dari proses pembuangan limbah cair oleh pembangkit listrik tenaga uap (PLTU). Perihal masalah pencemaran laut oleh limbah hasil olahan PLTU yang tentunya sangat berkaitan dengan hukum lingkungan khususnya telah mendapatkan perhatian yang lebih dari masyarakat untuk mencegah terjadinya hal tersebut.

Kesejahteraan umum sebagai tujuan negara dalam rumusan Pembukaan Undang-Undang Dasar Negera Republik Indonesia Tahun 1945 dimaknai sebagai kesejahteraan dalam arti yang luas, termasuk di dalamnya adalah tercukupinya kebutuhan sandang, pangan, papan, perumahan, pendidikan, kesehatan, dan energi, serta lingkungan hidup yang baik dan sehat. Dalam rangka mewujudkan kesejahteraan umum, pemerintah dapat dihadapkan pada pilihan sulit dan dilematis ketika 
akan menentukan kebijakan yang akan diambilnya. Pilihan sulit dan dilematis terjadi karena kebijakan yang diambil pemerintah menyangkut kepentingan publik. Makadalam mewujudkan kesejahteraan umum melalui serangkaian kegiatan pembangunan, di satu sisi akan mengeksplorasi dan mengeksploitasi lingkungan, dan di sisi lain pemerintah juga mengemban tanggung jawab untuk melindungi dan mengelola lingkungan.

Kondisi ini akan semakin kompleks karena selain pemerintah sebagai aktor penting dalam mewujudkan kesejahteraan masyarakat, juga pada kenyataannya dewasa ini kekuatan masyarakat termasuk korporasi telah memperlihatkan peran yang semakin besar. Gerak langkah pembangunan senantiasa harus mengacu kepada prinsip pembangunan berkelanjutan untuk masa depan yang lebih baik. Dalam konteks ini, salah satu tanggung jawab yang dimaksud adalah melindungi kawasan konservasi dan sumber daya laut secara berkelanjutan termasuk kawasan pesisir. Perlindungan ini penting karena kekayaan sumberdaya pesisir mendorong berbagai pihak pemangku kepentingan (stakeholder) seperti pemerintah, dunia usaha dan masyarakat untuk mengatur dan memanfaatkannya.

Indonesia merupakan negara kepulauan yang terdiri dari daerah pesisir, pulau-pulau kecil dan besar. Daerah pesisir merupakan wilayah yang unik, karena bentang konteks alam, wilayah pesisir merupakan tempat bertemunya daratan dan lautan. Sebagai wilayah transisi antara daratan dan lautan, pada wilayah pesisir terdapat ekosistem yang beragam dan produktif serta memiliki nilai ekonomi yang besar. Jika ditinjau dari segi wilayah, daratan maupun perairan di Indonesia, semuanya diperuntukan bagi kemakmuran rakyat (Resdianto Willem, 2018: 155).

Wilayah pesisir merupakan kawasan yang berfungsi budi daya (industri, pariwisata, pelabuhan, budi daya sumber daya laut, permukiman) dan kawasan berfungsi lindung (rawa pantai, hutan bakau, dan rumput laut). Menurut Dahuri bahwa pengelolaan wilayah pesisir dan pulau-pulau kecil sangat penting dan strategis disebabkan empat alasan pokok, yaitu (Resdianto Willem, 2018: 159):

1) Wilayah pesisir merupakan salah satu kawasan di bumi yang memiliki produktivitas hayati yang tinggi;

2) Wilayah pesisir banyak memiliki daerah-daerah yang indah dan nyaman untuk rekreasi dan pariwisata;

3) Wilayah pesisir pada umumnya mengalami tekanan lingkungan yang tinggi karena kepadatan penduduk dan intensitas pembangunan;

4) Wilayah pesisir, khususnya perairan pesisir merupakan sumber daya milik bersama. 
Dari beragamnya potensi sumber daya pesisir dan lautan di atas, sedikitnya terkait dengan 11 sektor kelautan yang dapat dikembangkan yaitu di antaranya (Ridwan Lasabuda, 2013: 96):

1) Perikanan tangkap;

2) Perikanan budidaya;

3) Industri pengolahan hasil perikanan;

4) Industri bioteknologi kelautan;

5) Pertambangan dan energi;

6) Pariwisata bahari;

7) Perhubungan laut;

8) Industri dan jasa maritim;

9) Sumber daya pulau-pulau kecil,;

10) Coastal forestry (mangrove); dan

11) Sda non konvensional.

Kawasan pesisir dan laut adalah bagian dari perlindungan lingkungan hidup dan merupakan amanat dari konstitusi, sebagaimana yang dijabarkan dalam berbagai peraturan perundang-undangan yang ada di Indonesia. Hal ini sejalan dengan diratifikasinya berbagai peraturan internasional antara lain Deklarasi Stockholm 19725 yang merupakan bagian dari lahirnya Undang-Undang Lingkungan Hidup Nomor. 4 Tahun 1982 tentang Ketentuan-Ketentuan Pokok Pengelolaan Lingkungan Hidup (KKLH) yang kemudian digantikan oleh UndangUndang Nomor 23 Tahun 1997 tentang Pengelolaan Lingkungan Hidup dan terakhir dilakukan pembaruan dengan Undang-Undang Nomor 32 Tahun 2009 tentang Perlindungan dan Pengelolaan Lingkungan Hidup.

Banyaknya pemanfaatan dan penyalahgunaan ruang pesisir dan laiut diberbagai aktivitas yang terus berlangsung menimbulkan berbagai dampak negatif. Dampak-dampak tersebut antara lain banyaknya peraturan yang dibuat oleh pemerintah dan saling tumpang tindih tanggung jawab sehingga menimbulkan polemik tersendiri bagi masyarakat. Termasuk juga diantaranya isu administrasi hukum seperti otonomi daerah, peningkatan PAD (Pendapatan Asli Daerah), konflikkonflik daerah dan sektoral merupakan persoalan yang harus dipecahkan bersama melalui manajemen kawasan pantai terpadu, dalam menunjang keberlanjutan pembangunan mengarah pada peningkatan kesejahteraan dan berkeadian bagi seluruh lapisan masyarakat yang dapat memanfaatkan daerah pesisir dan laut di sepanjang garis pantai Indonesia.

Proses bergulirnya moderenisasi dan globalisasi, menyebabkan kebutuhan primer dari masyarakat yang harus terpenuhi tentu menjadi hal penting. Hal inilah yang menginisiasi keberlangsungan PLTU untuk memenuhi kebutuhan dalam pemakaian listrik masyarakat harus terpenuhi secara kontinu. Tetapi tidak etis rasanya jika hanya 
menyalahkan masyarakat dan keberlangsungan PLTU. Selain itu, regulasi yang ada belum seluruhnya mengakomodir keberlangsungan proses pengolahan limbah cair PLTU yang di buang kelaut pesisir pantai yang juga tempat beroperasinya PLTU.

Penulisan ini bertujuan dapat dijadikan sebagai acuan dan masukan bagi pemerintah baik ditingkat pusat hingga daerah dalam menerapkan kebijakan-kebijakan sebagai langkah preventif dalam penanganan tindakan pencemaran lingkungan hidup, terkhusus di daerah pesisir pantai. Oleh karen itu, fokus kajian dalam penelitian ini yaitu tentang bagaimana pengaturan hukum Lingkungan tentang tanggung jawab negara atas pencemaran laut dari limbah cair buangan PLTU dikawasan pesisir pantai, bagaimana bentuk-bentuk tanggung jawab negara atas pencemaran laut dari limbah cair buangan PLTU dikawasan pesisir pantai.

\section{METODE PENELITIAN}

Penelitian ini adalah penelitian hukum yuridis normatif yang bersifat deskriptif kualitatif. Penelitian hukum normatif merupakansuatu proses guna menemukan suatu aturan hukum, prinsip-prinsip hukum, maupun doktrin-doktrin hukum guna menjawab isu hukum yang dihadapi (Marzuki, 2010: 35). Data utama yang dipergunakan adalah bahan hukum, baik bahan hukum primer, bahan hukum sekunder, dan bahan hukum tersier. (J. Supranto, 2003: 2) Bahan hukum yang dimaksud antara lain peraturan perundang-undangan yang mengatur tentang kawasan konservasi laut daerah, kawasan taman pesisir, dan perizinan terkait dengan pembangunan PLTU serta putusan pengadilan yang berkaitan dengan Izin Lokasi dan tata ruang. Selain itu, penelitian juga dilengkapi dengan data dari jurnal-jurnal ilmiah. Analisis data dilakukan dengan menggunakan analisis kualitatif dengan pendekatan statuta approach. Permasalahan yang telah dirumuskan dijawab dengan pendekatan statuta approach untuk menelaah peraturan perundangundangan terkait dengan permasalahan yang dihadapi

Data diolah dan dilakukan analisa secara kualitatif. Data penelitian ini diperoleh dari data sekunder yaitu data yang diambil dari bahan pustaka, meliputi antara lain buku-buku hukum, literatur, peraturan perundang- undangan, hasil penelitian terdahulu, artikel sumber lainnya yang berkaitan dengan penelitian ini. Data sekunder tersebut bersumber dari bahan hukum primer yang berupa peraturan perundang-undangan yang berkaitan dengan perencanaan dan pemanfaatan ruang berkeadilan. 


\section{PEMBAHASAN}

\section{Pengaturan Hukum dan Dampak Lingkungan Akibat Pencemaran Laut} Dari Limbah Cair Buangan PLTU Dikawasan Pesisir Pantai

Pembangkit Listrik Tenaga Uap (PLTU) Batubara merupakan tumpuan pemerintah dalam penyediaan listrik tanah air. Tidak hanya murah, bahan baku PLTU sendiri yaitu batu bara cukup mudah untuk di dapatkan karena tambang batu bara itu sendiri cukup banyak di Indonesia. Di Indonesia sudah ada hampir 100 PLTU Batubara yang tersebar di seluruh tanah air, yang sebagian besartersebar di pulau Jawa, dan pembangunan PLTU ini akan berlanjut dengan ditambahnya 35 PLTU lagi yang 10 buah PLTU nya dibangun di pulau jawa dan 25 sisanya dibangun di luar pulau jawa (Sabubu, 2020: 73)

Suhu merupakan salah satu variabel lingkungan yang paling penting untuk keberlangsungan hidup, pertumbuhan, dan reproduksi organisme akuatik. Suhu perairan tropis seperti di Indonesia dapat berubah, karena pengaruh lingkungan dalam jangka waktu tertentu. Suhu perairan dapat meningkat secara signifikan diakibatkan oleh aktivitas industri yang membuang limbah berupa air panas secara langsung ke laut, fenomena tersebut dikenal dengan pencemaran limbah air panas atau yang biasa disebut thermal waste pollution.

Pencemaran limbah air panas (thermal waste pollution) adalah masukan air dalam jumlah besar yang mengalami pemanasan dari satu atau sejumlah industri yang menggunakan sumber yang sama. Hal tersebut menyebabkan suhu airnya melebihi kondisi normalnya. Industri air pendingin menjadi sumber awal panas dimana pembangkit tenaga listrik menggunakan $80 \%$ air pendingin Sejauh ini, jumlah terbesar dari buangan limbah air panas ke laut adalah dari pembangkit listrik. Sekitar 20 juta meter kubik air pendingin dengan suhu 12 celsius di atas suhu normal air laut, dibuang oleh pembangkit listrik tenaga minyak atau batu bara dengan tenaga 1000 MW. Pengoperasian sebuah instalasi pada pembangkit listrik tenaga termal, baik yang berbahan bakar batubara, minyak bumi dan energi nuklir,pada umumnya menggunakan air laut sebagai pendingin.

Air pendingin yang masuk kembali ke laut memiliki suhu di atas suhu normal air laut. Limbah air panas dari instalasi pembangkit listrik biasanya dibuang secara langsung ke sungai sehingga meningkatkan suhu air dan menimbulkan pencemaran termal. Kenaikan suhu 10 derajat dapat mempercepat aktivitas metabolisme biota air menjadi dua kali dari biasanya. Masing-masing jenis biota air memiliki kecepatan metabolik yang berbeda, sehingga biota air hanya dapat hidup pada rentang suhu tertentu, dan berbeda untuk setiap kelompok biota. Populasi hewan air akan menurun pada suhu tinggi, dan hanya sedikit jenis hewan yang dapat hidup pada suhu di atas 40 celsius. Tumbuhan 
lebih tahan terhadap kenaikan suhu. Kenaikan suhu air akan menurunkan prosentasi kelarutan oksigen.

Perlindungan perairan pesisir Indonesia dari dampak limbah buangan pembangkit listrik tenaga uap batubara lemah, Aturan saat ini tak cukup memastikan laut terbebas pencemaran lmbah cair dari penyimpanan batubara dan abu hasil pembakaran dan operasional termal. Pengaturan dan pengetatan baku mutu mendesak dilakukan karena 91 persen PLTU batubara berada di pesisir yang membangkitkan listrik 24.435,96 megawatt (MW). Ke depan, 82 persen PLTU berbahan bakar batubara kapasitas 44.047 MW ada di pesisir (Rencana Usaha Penyediaan Tenaga Listrik / RUPTL 2018-2027). Landasan utama pencegahan dampak pencemaran air limbah dalam Peraturan Menteri Lingkungan Hidup Nomor 8 Tahun 2009 tentang Baku Mutu Air Limbah bagi Usaha dan/atau Kegiatan Pembangkit Listrik Tenaga Termal ialah turunan Peraturan Pemerintah Nomor 82 Tahun 2001 tentang Pengelolaan Kualitas Air dan Pengendalian Pencernaran Air. Aturan ini tak mengatur air laut sehingga Peraturan Menteri Lingkungan Hidup Nomor 8 Tahun 2009 tak bisa jadi acuan baku mutu air limbah PLTU batubara dibuang ke laut.

Perlindungan dan pengelolaan lingkungan hidup berdasarkan Pasal 1 angka (2) Undang-Undang Nomor 32 Tahun 2009 tentang Perlindungan dan Pengelolaan Lingkungan Hidup (UUPPLH) adalah upaya sistematis dan terpadu yang dilakukan untuk melestarikan fungsi lingkungan hidup dan mencegah terjadinya pencemaran dan atau kerusakan lingkungan hidup yang meliputi perencanaan, pemanfaatan, pengendalian, pemeliharaan, pengawasan, dan penegakan hukum. Pasal 65 ayat (1) Undang-Undang Nomor 32 Tahun 2009 tentang Perlindungan dan Pengelolaan Lingkungan Hidup, menyatakan bahwa "Setiap orang berhak atas lingkungan hidup yang baik dan sehat sebagai bagian dari hak asasi manusia". Selain itu pada Pasal 67 Undang-Undang tersebut menyatakan:"Setiap orang berkewajiban memelihara kelestarian fungsi lingkungan hidup serta mengendalikan pencemaran danatau kerusakan lingkungan hidup". Hal ini berarti antara masyarakat dan pemerintah perlu menjalin hubungan yang baik dalam melestarikan lingkungan hidup. Dalam pengaturan sumber daya alam, fungsi pemerintah adalah (Bambang, 2014: 29-30):

1) Mengatur dan mengembangkan kebijaksanaan dalam rangka pengelolaan lingkungan hidup;

2) Mengatur penyediaan, peruntukan, penggunaan, pengelolaan lingkungan hidup, dan pemanfaatan kembali sumberdaya alam, termasuk sumberdaya genetika;

3) Mengatur perbuatan hukum dan hubungan hukum antara orang dan/atau subyek hukum lainnya serta perbuatan hukum terhadap 
sumberdaya alam dan sumberdaya buatan, termasuk sumber daya genetika;

4) Mengendalikan kegiatan yang mempunyai dampak sosial;

5) Mengembangkan pendanaan bagi upaya pelestarian fungsi lingkungan hidup sesuai peraturan perundang-undangan yang berlaku.

Bentuk Tanggung Jawab Negara Terhadap Pencemaran Laut Dari Limbah Buangan PLTU Dikawasan Pesisir Pantai.

Dalam sistem pemerintahan modern, kekuasaan yang tidak diikuti oleh tanggung jawab penguasanya sudah ditinggalkan berhubung aspek pengendalian yang datang dari pihak masyarakat sudah demikian besar. Demikian juga tidak kecualinya kepada aspek pengelolaan sumber daya alam dan lingkungan. Negara tidak hanya berperan menguasai dan mendapatkan manfaat yang sebesar-besarnya, meskipun hal itu kemudian ditujukan untuk sebesar-besarnya kemakmuran rakyat (N.H.T. Siahan, 2009: 123)

Pengendalian dampak lingkungan hidup merupakan upaya untuk melakukan tindakan pengawasan terhadap suatu aktivitas yang dilakukan oleh setiap orang terutama perusahaan-perusahaan yang menimbulkan dampak besar terhadap lingkungan. Dalam hal ini dampak lingkungan hidup diartikan sebagai pengaruh perubahan ada lingkungan hidup yang diakibatkan oleh suatu usaha danatau kegiatan. Sehingganya perlindungan dan pengelolaan lingkungan hidup menjadi kewajiban bagi negara, pemerintah, dan seluruh pemangku kepentingan dalam pelaksanaan pembangunan berkelanjutan agar lingkungan hidup Indonesia dapat tetap menjadi sumber dan penunjang hidup bagi rakyat Indonesia serta makhluk hidup lain.

Sedangkan mengenai kebijaksanaan nasional lingkungan hidup mengacu pada nilai-nilai dasar dalam pelestarian lingkungan, yaitu sebagai berikut (Bambang P, 2014):

1) Pelestarian lingkungan dilaksanakan berdasarkan konsep Pembangunan Berkelanjutan, yaitu pembangunan yang mampu memenuhi aspirasi dan kebutuhan manusia pada generasi-generasi mendatang. Pembangunan berkelanjutan didasarkan atas kesejahteraan masyarakat serta keadilan dalam jangka waktu pendek, menengah dan panjang dengan keseimbangan pertumbuhan ekonomi, dinamisme sosial dan pelestarian lingkungan hidup;

2) Fungsi lingkungan perlu dilestarikan demi kepentingan manusia baik dalam jangka pendek, menengah, maupun jangka panjang. Pengambilan keputusan dalam pembangunan perlu memperhatikan pertimbangan daya dukung lingkungan sesuai fungsi lingkungannya. Daya dukung lingkungan menjadi kendala (constraint) dalam 
pengambilan keputusan dan prinsip ini perlu dilakukan secara kontinu dan konsekuen;

3) Pemanfaatan sumber daya alam tak terpulihkan perlu memperhatikan kebutuhan antar generasi. Pemanfaatan sumber daya alam terpulihkan perlu mempertahankan daya pemulihannya;

4) Setiap warga negara mempunyai hak untuk mendapatkan lingkungan yang baik dan sehat dan berkewajiban untuk melestarikan lingkungan. Oleh karenanya, setiap warga negara mempunyai hak untuk mendapatkan informasi lingkungan yang benar, lengkap dan mutahir.

5) Dalam pelestarian lingkungan, usaha pencegahan lebih diutamakan daripada usaha penanggulangan dan pemulihan;

6) Kualitas lingkungan ditetapkan berdasarkan fungsinya. Pencemaran dan perusakan lingkungan perlu dihindari; bila sampai terjadi pencemaran dan perusakan lingkungan, maka diadakan penanggulangan dan pemulihan dengan tanggung jawab pada pihak yang menyebabkan;

7) Pelestarian lingkungan dilaksanakan berdasarkan prinsip-prinsip pelestarian melalui pendekatan menejemen yang layak dengan sistem pertanggungjawaban.

Konsep pembangunan berkelanjutan yang telah diletakkan sebagai kebijaksanaan pada masa lalu, pada kenyataannya selama ini justru terjadi pengelolaan sumber daya alam yang tidak terkendali dengan akibat kerusakan lingkungan yang mengganggu kelestarian alam. Kebijakan yang diagendakan untuk mengantisipasi pencemaran dan kerusakan lingkungan wilayah pesisir pantai yaitu:

1) Konservasi keanekaragaman hayati;

2) Pengembangan bioteknologi; dan

3) Pengelolaan terpadu wilayah pesisir dan lautan.

Penanganan bagi ketiga aspek tersebut diarahkan pada upaya pelestarian dan perlindungan biologi pada tingkat genetik, spesies dan ekosistem, serta menjamin kekayaan alam, binatang dan tumbuhan di seluruh Indonesia. (Supriyanto, 2017). Dengan adanya pengelolaan limbah yang benar, maka air limbah dan gas buang dapat memenuhi baku mutu yang telah ditetapkan. Suatu kota harus mempunyai instalasi pengolahan air limbah domestik terpadu, baik limbah padat maupun cair. Dengan demikian, kualitas air laut di pesisir dapat terjaga. Limbah yang harus dikelola (waste management), antara lain:

1) Limbah padat domestik (solid waste),

2) Limbah Cair Domestik (sewage),

3) Limbah industri (industrial waste),

4) Limbah Bahan Berbahaya dan Beracun (Hazardous Waste),

5) Limbah Minyak,

6) Limbah Gas dan Debu. 
Hal di atas juga bisa dikaitkan dengan peran pemerintah selaku pelopor, tidak hanya menjalankan fungsinya selaku perumus kebijakan dan penyusunan rencana pembangunan saja, tetapi juga sebagai pelaksana pembangunan yang inovatif yang mampu memecahkan berbagai tantangan dan keterbatasan yang ada. Dengan peran pemerintah ini, tidak lengkap jika tidak diimbangi dengan program yang dibuat. Dalam hal ini ada IPLC, PROPER, dan pemerintah melakukan pengawasan, monitoring, maupun melakukan inspeksi mendadak ke perusahaan. Seperti IPLC adalah sebuah izin pembuangan limbah cair yang ditujukan pada kegiatan usaha atau industri yang menggunakan sumber-sumber air sebagai tempat pembuangan limbah cair dari hasil kegiatan usahanya. Dengan adanya IPLC ini diharapkan mampu mengurangi pencemaran yang terjadi (Maghfiro, M. Soeaidy, Mrozikin, $2013 ; 24)$.

Sejalan dengan Otonomi Daerah dimana menurut Undang-Undang Nomor 32 Tahun 2004 Tentang Pemerintahan Daerah dan setelah diubah menjadi Undang-Undang Nomor 23 Tahun 2014 Tentang Pemerintahan Daerah dalam Pasal 1 butir (6) menyebutkan bahwa "otonomi daerah adalah Hak, wewenang dan kewajiban daerah otonom untuk mengatur dan mengurus sendiri urusan pemerintahan dan kepentingan masyarakat setempat sesuai denganperaturan perundang-undangan". Dalam hal pelimpahan wewenang kepada pemerintah daerah di bidang pengelolaan lingkungan hidup mengandung maksud untuk meningkatkan peran masyarakat lokal dalam Perlindungan dan pengelolaan lingkungan hidup.

Sehubungan dengan permasalahan pencemaran lingkungan akibat industri membawa dampak yang luar biasa terhadap kehidupan masyarakat, karena bisa menimbulkan kerusakan lingkungan. Oleh karena itu, perlu penanganan yang serius untuk mengatasinya. Sehingga antara pemerintah, masyarakat dan lingkungan dibutuhkan hubungan timbal balik yang selalu harus dikembangkan agar tetap dalam keadaan yang serasi dan dinamis. Untuk melestarikan hubungan tersebut dibutuhkan adanya peran serta dari masyarakat maupun pemerintah itu sendiri. Hal ini agar tidak terjadi gangguan, masalah-masalah maupun perusakan yaitu pencemaran itu sendiri.

Untuk mencegah dan mengatasi limbah industri, pemerintah harus berperan aktif baik melalui perundang-undangan ataupun dengan cara yang lain. Pemerintah harus menggiatkan pembangunan yang berkesinambungan yaitu sustainable development dengan artian pembangunan yang berwawasan ke depan dengan maksud agar mampu dimanfaatkan oleh generasi sekarang maupun yang akan datang. Hakikat pembangunan adalah bagaimana agar kehidupan hari ke depan lebih baik dari hari ini. Namun demikian tidak dapat dipungkiri bahwa 
pembangunan akan selalu bersentuhan dengan lingkungan (Supriadi, 2008: 38).

Bentuk tanggung jawab negara lainnya dalam menangani pencemaran laut adalah melalui pemberianizin. Izin merupakan alat pemerintah yang bersifat yuridis preventif, dan digunakan sebagai instrument administrasi untuk mengendalikan perilaku masyarakat. Karena itu, sifat suatu izin adalah preventif, karena dalam instrument izin, tidak bisa dilepaskan dengan perintah dan kewajiban yang harus ditaati oleh pemegang izin. Selain itu, fungsi izin adalah represif. Izin dapat berfungsi sebagai instrument untuk menanggulangi masalah lingkungan disebabkan aktivitas manusia yang melekat dengan dasar perizinan. Artinya, suatu usaha yang memperoleh izin atas pengelolaan lingkungan, dibebani kewajiban untuk melakukan penanggulangan pencemaran atau perusakan lingkungan yang timbul dari aktivitas usahanya (Helmi, 2011:2)

Undang-Undang Nomor 32 Tahun 2009, Pasal 3 huruf (a) menyebutkan bahwa "Perlindungan danpengelolaan lingkungan hidup bertujuan melindungi wilayah Negara Kesatuan Republik Indonesia dari pencemaran dan atau kerusakan lingkungan hidup". Dalam kutipan Undang-Undang Nomor 32 Tahun 2009 dijelaskan bahwa: "ketentuan ini memberikan wewenang kepada pemerintah untuk mengambil langkahlangkah tertentu misal dibidang perpajakan sebagai insentif guna lebih meningkatkan pemeliharaan lingkungan dan dis-insentif untuk mencegah perusakan dan pencemaran lingkungan"(Jumali \& Farhan,et.al., 2017: 31).

Selain itu, penerapan good governance yang tepat, tentu sangat diharapkan perihal pengelolaan pembangunan yang berorientasi pada perlindungan dan pelestarian disektor lingkungan hidup. Good governance dapat dimaknai sebagai itikad baik pemerintah dalam hal ini sebagai unsur penyelenggara Negara dalam menegakkan dan atau menjalankan pengelolaan lingkungan hidup yang baik. Pengelolaan lingkungan hidup yang baik, tentu ditentukan oleh pemerintahan yang baik pula. good governance yang berkaitan dengan aspek pengelolaan lingkungan itu, juga berkaitan dengan pelaksanaan asas-asas umump emerintahan yang baik.

Menurut Hyronimus, dari 13 (tiga belas) asas umum pemerintahan yang baik, yang berkaitan dengan urusan lingkungan hidup antara lain asas kepastian hukum, keseimbangan, tidak mencampur adukkan kewenangan, keadilan dan kewajaran, menanggapi harapan yang ditimbulkan, dan asas penyelenggaraan kepentingan (Rhiti, 2005: 48).

Pemahaman yang benar mengenai good governance terutama dalam upaya pengelolaan lingkungan hidup yang baik, tidak hanya ditekankan pada kemauan politik (political will) pemerintah semata, tetapi diharapkan dari semua unsur masyarakat yang memiliki kepedulian terhadap lingkungan hidup. Terwujudnya good governance merupakan prasyarat 
pokok dari pengelolaan lingkungan hidup yang efektif dan tepat sasaran, karena pengelolaan lingkungan hidup yang efektif dan terpat sasaran tergantung pada berfungsinya sistem politik yang menjamin demokrasi dan rule of law.

Good governance hanya bias dicapai jika pemerintah dalam melaksanakan tugasnya berpedoman kepada konsep rule of law, yang mempunyai lima karakteristik yang diantaranya sebagai berikut (Achmad S, 2001: 87).

1) Pemerintah melaksanakan kewenangannya berdasarkan supremasi hokum;

2) Pemerintah menjamin kepastian hokum;

3) Pemerintah harus menciptakan hukum yang responsif yang mampu menyerap aspirasi masyarakat;

4) Pemerintah harus melaksanakan hukum secara konsisten dan non diskriminatif melalui penciptaan mekanisme menjalankan sanksi;

5) Pemerintah harus menciptakan dan menjamin terlaksananya independen peradilan.

Pemerintahan yang sudah mampu mewujudkan good governance belum tentu memiliki kepedulian terhadap aspek keberlanjutan ekosistem. Seperti yang diusung oleh environmetalism. Oleh sebab itu pemerintah yang telah mengupayakan aktualisasi prinsip-prinsip good governance masih memerlukan persyaratan tambahan yaitu mengaitkan seluruh kebijakan pembangunan dengan prinsip-prinsip keberlanjutan ekologi (ecological sustainability) agar dapat dikatakan sebagai good environmental governance (Santosa, 2008: 131)

Kemudian sebagai sistem, environmental governance memiliki aspekaspek di antaranya sosial budaya, interaksi politik dan ekonomi diantara banyak aktor dalam masyarakat madani. Dalam mengelola dan melindungi lingkungan hidup di sekitar diperlukan kerjasama antara manusia, manusia sangat berperan penting untuk mengelola dan melindungi lingkungan hidup tempat dimana ia tinggali. (Rodiah 2020:4445). Mulai dari pemerintah dan sampai masyarakat mempunyai hak dan kewajiban yang sama dalam mengelola dan melindungi lingkungan tanpa terkecuali. Tidak terbatas dimanapun domisilinya. Baik masyarakat desa, pelosok maupun kota, menjadi bagian penting dari perwujudan lingkungan hidup yang baik dan sehat. Keberadaan masyarakat akan efektif sekali jika perannya dalam mengontrol pengelolaan lingkungan yang ada (Samsul, 2014: 174)

Konsep good governance dalam lingkungan atau bisa disebut dengan environmental governance, melihat negara dan masyarakat sebagai obyek sekaligus subyek pada usaha pelestarian lingkungan. Negara sebagai suatu organisasi yang memiliki kontrol terhadap sumberdaya dan kekuasaan, memiliki kemampuan mengubah kondisi alam dalam skala 
yang masif. Oleh karena itu, nasib lingkungan hidup sangat ditentukan oleh kemampuan menertibkan perilaku negara agar konsisten dengan kaidah-kaidah ekologis (Rodiah, 2020: 45)

Friedman mengemukakan empat fungsi negara, yaitu: 1) sebagai provider,negara bertanggung jawab dan menjamin suatu standar minimum kehidupan secara keseluruhan dan memberikan jaminan sosial lainnya; 2) sebagai regulator, negaramengadakan aturan kehidupan bernegara; 3) sebagai entrepreneur, negaramenjalankan sektor ekonomi melalui badan usaha milik negaradaerah danmenciptakan suasana yang kondusif untuk berkembangnya bidang-bidang usaha; 4I sebagai umpire, negara menetapkan standar-standar yang adil bagi pihak yangbergerak di sektor ekonomi, terutama antara sektor negara dan sektor swasta atauantar bidang-bidang usaha-usaha tertentu (Hakim, 2010: 48).

Ada beberapa instrumen yang dapat dikembangkan dalam mencegah terjadinya pencemaran dan kerusakan di wilayah pesisir. Menurut Pasal 14 Undang-Undang Nomor 32 Tahun 2009 tentang Perlindungan dan Pengelolaan Lingkungan Hidup. Instrumen pencegahan pencemaran dan/atau kerusakan lingkungan hidup terdiri atas:

1) Kajian lingkungan hidup strategis (KLHS);

2) Tata ruang;

3) Baku mutu lingkungan hidup;

4) Kriteria baku kerusakan lingkungan hidupl

5) Amdal;

6) UKL-UPL;

7) Perizinan;

8) Instrumen ekonomi lingkungan hidup;

9) Peraturan perundang-undangan berbasis lingkungan hidup;

10) Anggaran berbasis lingkungan hidup;

11) Analisis risiko lingkungan hidup;

12) Audit lingkungan hidup; dan

13) Instrumen lain sesuai dengan kebutuhan dan/atau perkembangan ilmu pengetahuan.

\section{SIMPULAN}

Berdasarkan uraian tersebut di atas, dapat disimpulkan bahwa Untuk mencegah dan mengatasi limbah industri, pemerintah harus berperan aktif baik melalui perundang-undangan ataupun dengan cara yang lain seperti dengan program yang dibuat. Dalam hal ini ada IPLC, PROPER, dan pemerintah melakukan pengawasan, monitoring, maupun melakukan inspeksi mendadak ke perusahaan. Seperti IPLC, IPLC adalah sebuah izin pembuangan limbah cair yang ditujukan pada kegiatan usaha atau industri yang menggunakan sumber-sumber air sebagai tempat 
pembuangan limbah cair dari hasil kegiatan usahanya. Dengan adanya IPLC ini diharapkan mampu mengurangi pencemaran yang terjadi. Negara, dalam hal ini pemerintah pusat hingga pemerintah daerah mampu melaksanakan prinsip-prinsip good governance dengan mengaktualiasikan prinsip-prinsip keberlanjutan ekologi (ecological sustainability) dalam seluruh kebijakan pembangunan baik ditingkat pusat hingga daerah demi terwujudnya good environmental governance, dan juga pemerintah harus menggiatkan pembangunan yang berkesinambungan yaitu dengan konsep sustainable development dengan artian pembangunan yang berwawasan ke depan dengan maksud agar mampu dimanfaatkan oleh generasi sekarang maupun yang akan datang.

\section{DAFTAR PUSTAKA \\ Buku-buku}

Agoes Soegianto. (2010). Ilmu Lingkungan, Sarana Menuju Masyarakat Berkelanjutan. Surabaya: Airlangga University Press.

Lukmanul Hakim, (2010). Kedudukan Hukum Komisi Negara di Indonesia; Eksistensi Komisi-komisi Negara (State Auxiliary Agency) Sebagai Organ Negara yang Mandiri Dalam Sistem Ketatanegaraan, Program Pasca Sarjana Universitas Brawijaya Malang, Puskasi Universitas Widyagama malang dan Setara Press (Kelompok Penerbit Intrans), Malang.

N.H.T. Siahaan. (2009). Hukum Lingkungan, Pancuran Alam. Jakarta.

Pandji Santosa. (2008). Administrasi Publik: Teori dan Aplikasi Good Governance, Refrika Adifama. Bandung.

Peter Mahmud Marzuki. (2010). Penelitian Hukum. Kencana Prenada. Jakarta.

Supriadi. (2008). Hukum Lingkungan di Indonesia. Sinar Grafika. Jakarta.

\section{Jurnal-Jurnal}

Affila, Afnila, Rafiqoh Lubis, (2019). "Penegakan Hukum Administratif Oleh Dinas Lingkungan Hidup Dalam Pencegahan Pencemaran dan Perusakan Lingkungan Hidup", Jurnal Bina Hukum Lingkungan, P-ISSN 2541-2353, E-ISSN 2541-531X Volume 3, Nomor 2, April. DOI: $10.24970 /$ jbhl.v3n2.11.

Bambang Pramudyanto. (2014). "Pengendalian Pencemaran Dan Kerusakan Di Wilayah Pesisir", Jurnal Lingkar Widyaiswara (www.juliwi.com) Edisi 1 No. 4, Oktober - Desember, p.21 - 40 ISSN: 2355-4118.

Evi Purnama Wati,"Perlindungan Dan Pengelolaan Lingkungan Hidup 
Dalam Pembangunan Yang Berkelanjutan", Jurnal Bina Hukum Lingkungan, P-ISSN 2541-2353, E-ISSN 2541-531X Volume 3, Nomor 1, Oktober 2018 DOI: 10.24970/jbhl.v3n1.9

Helmi, "Kedudukan Izin Lingkungan Dalam Sistem Perizinan Di Indonesia", Jurnal Ilmu Hukum VOLUME2 No. 1 Agustus 2011.

Ima Maghfiro, M. Saleh Soeaidy, M.Rozikin, "Analisis Peran Pemerintah Dalam Mengatasi Limbah Industri Pabrik Gula Tjoekir", Jurnal Administrasi Publik (JAP,) Vol.1, No.3

Jumali, Nurul Farhan,et.al. "Peran Pemerintah Daerah Dalam Mengoptimalisasi Penanganan Pencemaran Lingkungan Di Wilayah Pesisir Kota Batam", Jurnal Selat, Volume. 5 Nomor. 1, Oktober 2017. Open Access at: http:/ /ojs.umrah.ac.id/index.php/selat.

Purniawati, Kasana dan Rodiah. "Good Environmental Governance In Indonesia (Perspective of Environmental Protection And Management" The Indonesian Journal of International Clinical Legal Education.DOI: 10.15294/ ijicle.v2i1.37328.https:/ /journal.unnes.ac.id/sju/index.php/iccle 2020

Rachmad Safaat, Dwi Yono, “Peran Negara Dalam Pengelolaan Sumber Daya Kelautan Berbasis Kearifan Lokal Untuk Kesejahteraan Yang Berkeadilan", Legality, ISSN: 2549-4600, Vol.25, No.1, Maret 2017Agustus 2017.

Resdianto Willem, "Pemanfaatan Ruang Pesisir Dan Laut Yang Berkeadilan", Jurnal Bina Hukum Lingkungan, P-ISSN 2541-2353, EISSN 2541-531X Volume 2, Nomor 2, April 2018 DOI: 10.24970/jbhl.v2n2.13.

Ridwan Lasabuda, "Pembangunan Wilayah Pesisir Dan Lautan Dalam Perspektif Negara Kepulauan Republik Indonesia", Jurnal Ilmiah Platax, Vo. 11 No. 2, 2013.

Supriyato, "Strategi Pengendalian Kerusakan dan Pencemarankawasan Pesisir Pantai", Jurnal Saintek Maritim, Vol. XVI Nomor 2, Maret 2017.

Theo Alif Sabubu, "Pengaturan Pembangkit ListrikTenaga Uap Batubara Di Indonesia Prespektif Hak Atas Lingkungan Yang Baik Dan Sehat", Jurnal Lex Renaissance No. 1 Vol. 5 Januari 2020.

Yoshua Hamonangan Sihombing, (2017).“Optimalisasi Hukum laut nasional untuk Pengembangan Potensi sumber daya Perikanan di Indonesia", Jurnal Hukum Lingkungan, Vol. 3 Issue 2, Maret 